\title{
MEMBANGUN KESADARAN SPIRITUAL DI ABAD 21: DARI AKTIVITAS MENGAGUMI HINGGA MENGINSPIRASI60
}

\author{
Unik Hanifah Salsabila 61 \\ E-mail: unik.salsabila@pai.uad.ac.id \\ Dosen Program Studi Pendidikan Agama Islam \\ Pada Fakultas Agama Islam \\ Universitas Ahmad Dahlan Yogyakarta
}

\section{Abstrak}

Makalah ini membahas konsepsi umum Pendidikan Islam dalam konteks orientatif, yang semestinya menjadi spirit pengembangan gagasan besar (powerful ideas) di dalam praktik pembelajaran. Miskonsepsi di dalam sistem Pendidikan Islam menimbulkan paradigma konvensional terhadap konten ajaran Islam untuk menghadapi laju zaman. Penulis melalui studi lapangan kualitatif, berupaya menyajikan gagasan inovatif model pengembangan Pendidikan Islam praksis untuk menyikapi darurat kebutuhan literasi spiritual melalui pola rekonstruksi pengalaman menggunakan integrasi tujuh fase belajar yang menginspirasi, yakni mengagumi, menghayati, meneliti, menghubungkan, mengkolaborasi, mengaktualisasi, dan memberi. Model revitalisasi kebermaknaan pembelajaran tersebut didesain untuk merespon problematika kontemporer di dalam sistem Pendidikan Islam.

\section{Kata Kunci: Pembelajaran, Mengagumi, Kesadaran Spiritual, Menginspirasi, Alur Pembelajaran}

\section{Abstract}

This paper discusses the general conception of Islamic Education in an orientation context, which should be the spirit of developing great thinking in learning practices. A misconception in the Islamic Education system raises the conventional paradigm of Islamic teaching content to accelerate the times. The author, through a qualitative field study, discussed innovative research of the development model of Islamic praxis to address the emergency needs of religious literacy through a pattern of supporting development using seven phases of learning that inspire, admire, appreciate, connect, connect, collaborate, actualize, and give. This

60 Title in English: Building Spiritual Literacy in the 21st Century: From Admire to Inspire

${ }^{61}$ Mengambil konsenterasi keilmuan pada bidang teknologi pendidikan 
Unik Hanifah Salsabila : Membangun Kesadaran Spiritual Di Abad 21: Dari Aktivitas Mengagumi Hingga Menginspirasi

sustainable learning revitalization model is designed to respond to contemporary problems in the Islamic Education system.

\section{Keywords: Learning, Admiring, Spiritual Awareness, Inspiring, Learning Flow}

\section{A. PENDAHULUAN}

Filosofi penciptaan alam semesta membawa misi transformatif di setiap tahap derivasinya. Salah satunya dapat ditemukan pada kajian mengenai orientasi penciptaan manusia62. Demikian pula hakikat pendidikan yang disandarkan pada perspektif filosofis, sehingga menghasilkan makna berupa kata tarbiyah63. Keduanya memiliki karakter filosofis serupa yang tersinergi menjadi media katalis transformasi nilai dalam bentuk aktivitas merawat, menumbuhkan, serta mengembangkan sebuah potensi fitrah. Sinergitas yang terbentuk antara orientasi penciptaan manusia dengan hakikat pendidikan dalam upaya mewujudkan misi tranformatif itulah yang selanjutnya menjadi konsep dasar bagi pengembangan Pendidikan Islam, baik dari aspek tujuan, visi, misi, maupun aplikasi. Maka sudah sewajarnya jika setiap aktivitas pembelajaran yang dikembangkan oleh sistem Pendidikan Islam mengacu pada grand design total human development dengan menjadikan orientasi penciptaan manusia, yakni hamba dan khalifah di muka bumi, sebagai sebuah gagasan besar (powerful ideas) untuk membangun rekonstruksi makna yang fundamental di dalam diri peserta didik. Pendidikan Islam harus dapat merepresentasikan gagasan besar tersebut melalui ketiga domainnya yakni iman (kognitif), Islam (psikomotorik), dan ihsan (afektif) (Tauhidi, 2018), yang selaras dengan perspektif filosofis

62 Lihat QS. Ar Ra'ad/13:2-4.

${ }^{63}$ Lihat QS. Al Hajj/22:5, QS. Ash Shu'ara/26:18, dan QS. Al Isra/17:24. 
Unik Hanifah Salsabila : Membangun Kesadaran Spiritual Di Abad 21: Dari Aktivitas Mengagumi Hingga Menginspirasi

mengenai kajian epistimologi, ontologi, dan aksiologi sebagai bangunan dasar spiritualitas.

Dewasa ini, Pendidikan Islam dihadapkan pada kompleksitas tantangan aktualisasi penyesuaian konten, antara pembelajaran normatif dengan kontekstual, sehingga menghasilkan formulasi untuk mengakomodir kebutuhan academic user di abad 21. Ketepatan dan kecepatan sistem Pendidikan Islam dalam merespon dialektika tersebut menjadi tolok ukur standar pengembangan generasi dan peradaban di masa depan. Sebagai langkah awal kesadaran Pendidikan Islam dalam menyikapi kondisi kritis tersebut, perlu dilakukan redefinisi dan revitalisasi orientasi sistemik secara massif. Secara organisatoris langkah tersebut mengarah pada aktivitas pembenahan standar isi dan sasaran mutu kelembagaan, sedangkan secara aplikatif langkah tersebut mengarah pada aktivitas pembenahan praktik belajar di lingkungan tripusat pendidikan (Patria \& Mutmainah, 2018), yakni sekolah, keluarga, dan masyarakat. Kajian ekologis mengindikasikan perkembangan individu sebagai hasil interaksi seseorang dengan lingkungan sekitarnya (Salsabila, 2018). Dalam konteks ini, lingkungan mikrosistem menjadi subsistem yang relevan dengan praktik Pendidikan Islam, yakni meliputi lingkungan sekolah dan keluarga sebagai agen sosial aktif di mana peserta didik tidak hanya menerima pengalaman, melainkan juga berkontribusi membangun setting. Kecenderungan sifat potensial sebagai agen transformasi nilai menjadikan sekolah dan keluarga sebagai ruang inovatif realisasi praktik pembelajaran bermakna yang mengarahkan asumsi normatif dan transmitif sistem Pendidikan Islam menjadi bernilai progresif. 
Unik Hanifah Salsabila : Membangun Kesadaran Spiritual Di Abad 21: Dari Aktivitas Mengagumi Hingga Menginspirasi

\section{B. PEMBAHASAN}

1. Menghadapi Tantangan Abad 21 Melalui Konsep Keberlanjutan Aktifitas

Menyikapi problematika pembelajaran milenial, Dr. Dawud Tauhidi menyuarakan konsep dan implementasi keterpaduan di dalam sistem Pendidikan Islam, salah satunya melalui kompetensi tujuh pilar literasi yang harus dikuasai oleh peserta didik di abad 21, yakni literasi spiritual, moral, intelektual, fisik, interpersonal, budaya, dan sosial. Adapun keselarasan implementasi pengusaan ketujuh literasi tersebut tentu memerlukan dukungan sistemik yang terstruktur dari komponen stakeholder sekolah, terutama pada jenjang pendidikan dasar. Salah satu strategi praktik implementasinya ialah melalui penyederhanaan definisi ketujuh capaian literasi ke dalam alur pembelajaran sehingga membentuk rangkaian aktifitas atau fase pembelajaran tertentu yang dapat merepresentasikan substansinya, misalnya fase mengagumi, menghayati, meneliti, menghubungkan, mengkolaborasi, mengaktualisasi, dan diakhiri dengan fase memberi (Salsabila, 2017a). Pola integrasi keseluruhan aktivitas tersebut menjadi lebih bermakna melibatkan berbagai macam materi dan metode belajar di bawah satu payung tema berbasis proyek (Project Based Learning).

Fase mengagumi sebagai peletakan dasar pemahaman filosofis yang diperoleh melalui aspek Spiritual Literacy berupakan mengembangkan serangkaian aktifitas pengenalan tanda-tanda keberadaan Allah di dalam setiap penciptaan alam semesta (ayat kauniyah), sehingga proses pembelajaran pada fase ini memunculkan serangkaian 
Unik Hanifah Salsabila : Membangun Kesadaran Spiritual Di Abad 21: Dari Aktivitas Mengagumi Hingga Menginspirasi

pengalaman belajar yang dapat memicu rasa kagum dan heran yang alamiah yang secara intuitif dapat mengaktifkan respon kesadaran untuk bertuhan, rasa heran dan ingin tahu, serta minat belajar (curiosity) di dalam diri peserta $\operatorname{didik}^{64}$ sebagai representasi dari potensi fitrah yang dimiliki oleh setiap manusia. Pada fase menghayati, peserta didik dapat mulai dihadapkan dengan kondisi-kondisi tertentu yang menyuguhkan realitas anomali sehingga memantik keterlibatan emosional yang menghasilkan ingatan laten (long term memory). Kebermaknaan yang dimunculkan melalui fase menghayati cenderung berpotensi untuk mengubah paradigma belajar normatif konvensional menjadi aktivitas menantang untuk menganalisis metafora di dalam filosofi penciptaan alam semesta (Tauhidi, 2018).

Tahap berikutnya ialah Pembelajaran Berbasis Masalah (Problem Based Learning) melalui fase meneliti yang terdiri atas identifikasi masalah, perencanaan strategi, trial and error, pemanfaatan informasi digital, pembuatan framework, refleksi temuan, dan pengambilan simpulan atas pemahaman baru yang ditemukan. Fase meneliti merupakan bangunan dasar intelektual yang terfokus pada pembentukan logika komputasional (Salsabila, 2017a). Selanjutnya pemahaman yang diperoleh semakin diperkuat melalui pengkajian lebih lanjut di dalam aspek metode, konteks, dan logika melalui konektivitas keilmuan interdisipliner pada fase menghubungkan untuk menciptakan harmonisasi batas antara imajinasi, idealisme teori, dan realitas. Kompleksitas keilmuan yang diperoleh peserta didik juga dikonversikan ke dalam aspek interpersonal yang melibatkan heterogenitas

64 Lihat QS. Al Jumu'ah/62: 2. 
Unik Hanifah Salsabila : Membangun Kesadaran Spiritual Di Abad 21: Dari Aktivitas Mengagumi Hingga Menginspirasi

keterlibatan sosial untuk menghasilkan proyek inovatif melalui fase mengkolaborasi (Salsabila, 2018). Menjelang akhir proses belajar, peserta didik diberi ruang transformasi di dalam fase mengaktualisasi melalui identifikasi penerapan keilmuan ke dalam perubahan life style. Pada fase inilah sekaligus dapat dilakukan penilaian otentik terhadap serangkaian proses belajar yang telah dialami oleh peserta didik sesuai dengan level pemahamannya.

Pada tahap akhir pembelajaran dilakukan fase memberi, yang merupakan refleksi kebermaknaan dan kebermanfaatan secara implementatif melalui pelayanan sosial sebagai kulminasi dari proses pembelajaran yang kontekstual. Peserta didik dilibatkan untuk memberikan kontribusi sosial sesuai dengan pembelajaran yang telah diperoleh kepada masyarakat di lingkungan sekolah maupun rumah, baik melalui acara khusus yang dirancang pihak sekolah, maupun inisiatif pribadi setiap peserta didik sebagaimana pemahaman yang diterima (Salsabila, 2017). Pada tahap akhir pembelajaran, harapannya peserta didik telah menemukan pola kekaguman terhadap keajaiban penciptaan alam, dan secara alami membentuk kesadaran untuk menjadi sosok inspirasional yang dapat berkontribusi terhadap alam semesta sebagaimana filosofi penugasan manusia di muka bumi, yakni menjadi khalifah yang senantiasa menjaga dan membawa kebermanfaatan bagi semesta alam.

2. Integrated Learning Model: Investasi Kasih Sayang

Sinergitas keterlibatan keluarga dan sekolah sebagai lingkungan mikrosistem terdekat tentunya memberikan tanggungjawab besar bagi terpeliharanya potensi fitrah yang 
merupakan modal awal penerimaan konsep tauhid dalam diri peserta didik pada setiap level pembelajaran. Perilaku keagamaan seorang anak sangat dipengaruhi oleh pembentukan habit spiritual di dalam keluarganya. Oleh karena itu keteladanan merupakan sumber pengalaman yang paling berpengaruh dalam pembentukan nilai-nilai yang menjadi komponen spiritual literacy. Iklim positif yang dibangun melalui pembentukan ekosistem sekolah tidak dapat menjadi media transformasi spiritualitas yang cukup jika konsep pendidikan di dalam keluarga tidak memiliki framework yang serupa dalam konteks orientasi tujuan Pendidikan Islam (Binder, 2011). Salah satu model pembelajaran terintegrasi yang menjadi refleksi keberlanjutan proses pembelajaran bermakna di sekolah ialah melalui adaptasi habit training ala Nabi Muhammad SAW yang mengedapkan metode komunikasi hikmah sebagai dasar pengembangan spiritual literacy di dalam keluarga (Salsabila, 2018). Orangtua memiliki kecenderungan fitrah potensial untuk menjadi role model di dalam kehidupan pribadi peserta didik, sehingga pembentukan habit spiritual di dalam keseharian peserta didik di lingkungan rumah akan menjadi stimulator aktif baik secara langsung maupun dalam proses pemeliharaan fitrah. Alur keseharian yang dibentuk oleh keluarga juga akan berimplikasi pada pembentukan pola pikir peserta didik.

\section{KESIMPULAN}

Tataran konsepsi idealis menempatkan praktik Pendidikan Islam sebagai jalinan mata rantai yang utuh dan berkesinambungan untuk mencapai tujuan yang komprehensif. 
Unik Hanifah Salsabila : Membangun Kesadaran Spiritual Di Abad 21: Dari Aktivitas Mengagumi Hingga Menginspirasi

Akan tetapi, mayoritas sistem Pendidikan Islam justru mengalami kesalahpahaman konsep, yang menyebabkan terjadinya pemisahan disiplin akademik, baik dalam aspek keyakinan maupun konten keilmuan. Ironisnya, aspek normatif ajaran Islam menyebutkan secara mendetail bahwa kehidupan seorang muslim secara universal, terbangun di atas prinsip keyakinan dan refleksi tindakan sekaligus. Konsepsi tersebut seakan mensyaratkan bahwa deklarasi keimanan seseorang harus dapat diterjemahkan ke dalam setiap tindakan dan pola interaksi sosial. Realitas pengikisan makna spiritual generasi muslim menyebabkan problem laten degradasi moral di dalam kehidupan bermasyarakat.

Fenomena tersebut semestinya menjadi titik balik kesadaran sistem pendidikan Islam untuk mengevaluasi keberlangsungan proses pembelajarannya. Aktivitas belajar yang terfokus pada pemberian informasi mengenai pelaksanaan ritual Islam dan wawasan seputar dunia Islam, membentuk pola belajar yang membosankan, tidak menginspirasi, dan bahkan tidak relevan dengan kebutuhan generasi masa depan. Pada akhirnya Pendidikan Islam hanya dipandang sebagai mata pelajaran dogmatif yang konvensional. Oleh karena itu, diperlukan praktik model pembelajaran yang terintegrasi di dalam lingkup keseharian universal peserta didik melalui pengalaman-pengalaman bermakna, sehingga meninggalkan kesan mendalam, menginspirasi, berkemajuan, dan juga kontekstual terhadap tantangan disrupsi zaman. Melalui model pembelajaran yang bermakna, diharapkan generasi muslim terdidik menjadikan Islam sebagai identitas kebanggaan, yang direpresentasikan melalui: Islam sebagai gaya hidup, dan Islam untuk memahami kehidupan. 
Unik Hanifah Salsabila : Membangun Kesadaran Spiritual Di Abad 21: Dari Aktivitas Mengagumi Hingga Menginspirasi

\section{DAFTAR PUSTAKA}

Binder, M. J. (2011). I Saw the Universe and I Saw the World: Exploring Spiritual Literacy with Young Children in a Primary Classroom. International Journal of Children's Spirituality, 16(1), 19-35. https://doi.org/10.1080/1364436X.2010.542132

Patria, A. S., \& Mutmainah, S. (2018). Using Textbook Illustration as Media for Developing Character among Primary Students: Some Research-based Suggestion. Journal of Education and Learning (EduLearn), 12(1),

52. https://doi.org/10.11591/edulearn.v12i1.6509

Salsabila, U. H. (2017a). Implementasi Pendidikan Agama Islam Berbudaya Nirkekerasan di SDIT LHI Yogyakarta. UIN Sunan Kalijaga. Diambil dari http://digilib.uinsuka.ac.id/28232/1/1520411044_bab-i_iv-atau-v_daftarpustaka.pdf

Salsabila, U. H. (2017). Refleksi Peace-Education dalam Transformasi Kurikulum Pendidikan Islam (Solusi Alternatif Resolusi Konflik Melalui Pendidikan Formal). Journal Al-Manar, 6(2). Diambil dari https://journal.staimsyk.ac.id/index.php/almanar/article/view $/ 31$

Salsabila, U. H. (2018). Teori Ekologi Brofenbrenner sebagai Sebuah Pendekatan dalam Pengembangan Kurikulum Pendidikan Agama Islam. Journal Al-Manar, 7(1). Diambil dari https://journal.staimsyk.ac.id/index.php/almanar/article/view $/ 72$

Tauhidi, D. (2018). A Vision of Effective Islamic Education. Islamic World (Editor: Anas Coburn), http://islamic-world. net, 1-4. Diambil dari papers3://publication/uuid/bad197fe-7765-409284ed-1cf1b0597e49 
Unik Hanifah Salsabila : Membangun Kesadaran Spiritual Di Abad 21: Dari Aktivitas Mengagumi Hingga Menginspirasi 